\title{
The Evaluation of Flash Point and Cold Filter Plugging Point with Blends of Diesel and Cyn-Diesel Pyrolysis Fuel for Automotive Engines
}

\author{
Fionnuala Murphy, G. Devlin* and K McDonnell
}

Biosystems Engineering, University College Dublin, Dublin 4, Ireland

\begin{abstract}
The production of synthetic fuels from alternative sources has increased in recent years as a cleaner, more sustainable source of transport fuel is now required. The European Commission has outlined renewable energy targets pertaining to transport fuel which must be met by 2020. In response to these targets Ireland has committed, through the Biofuels Obligation Scheme of 2008, to producing 3\% of transport fuels from biofuels by 2010 and 10\% by 2020. In order to be suitable for sale in Europe, diesel fuels and biodiesels must meet certain European fuel specifications outlined in the EN 590:2009 standard. The aim of this paper was to prepare blends of varying proportions of synthetic diesel (Cyn-diesel) fuel, produced from the pyrolysis of plastic, vs regular fossil diesel. The flash point $\left({ }^{\circ} \mathrm{C}\right)$ and cold filter plugging point $\left({ }^{\circ} \mathrm{C}\right)$ of these blends as well as of the conventional petroleum diesel fuel were analysed in relation to compliance with the European fuel standard EN 590. The results confirmed that blending of Cyn-diesel with conventional petroleum diesel has a highly significant effect on the properties of the resulting fuel blend. The results show that by increasing the Cyn-diesel content of the blend, the flash point of the blend decreases and the cold filter plugging point increases. Furthermore, comparing the fuel blends to EN 590 specifications has highlighted significant trends. The cold filter plugging points of all of the fuel blends are in compliance with EN 590 specifications. However, only blends of up to, and including, 40\% Cyn-diesel are in compliance with EN 590 specifications for flash point. This analysis shows that a blend of $40 \%$ Cyndiesel is in compliance with all of the EN 590 specifications examined, and as such could be placed on the European fuel market (provided that the blend meets the requirements for the other properties in the EN 590 specification). This finding highlights the potential for Cyn-diesel blends to be incorporated into the European and national renewable energy targets.
\end{abstract}

Keywords: Alternative fuels, waste-to-energy, EU biofuel targets, fuel properties, flash point, cold filter plugging point, diesel, Cyn-diesel.

\section{INTRODUCTION}

\subsection{Biofuel Policy}

\subsubsection{European Biofuel Policy}

The European Council released a new Directive in 2009 on the promotion and use of energy from renewable sources. This directive amends and repeals both Directive 2001/77/EC of the European Parliament and of the European Council of 27 September 2001 on the promotion of electricity produced from renewable energy sources in the internal electricity market and Directive 2003/30/EC of the European Parliament and of the European Council of 8 May 2003 on the promotion of the use of biofuels or other renewable fuels in transport [1]. The directive confirms the European Community's commitment to the previous mandatory targets of a $20 \%$ share of energy from renewable sources in overall Community energy consumption by 2020 and a mandatory $10 \%$ minimum target of transport fuelled by renewable by 2020 . These renewable sources may encompass electric transport as well as biofuels. The mandatory $10 \%$ target for transport to be achieved by all Member States should therefore be defined as that share of

*Address correspondence to this author at the Biosystems Engineering, University College Dublin, Dublin 4, Ireland; Tel: 003531716 7458/7418; Fax: 003531716 7415; E-mail: ger.devlin@ucd.ie final energy consumed in transport which is to be achieved from renewable sources as a whole, and not from biofuels alone [1].

\subsubsection{Irish Biofuel Policy}

As a response to the above mentioned European biofuels targets, Ireland developed a Biofuels Obligation Scheme (BOS) in order to meet the required targets. The biofuels obligation scheme was to ensure that a certain percentage of the transport fuel used in the state by 2010 consists of biofuels. The penetration level of the BOS was to be $3 \%$ (by volume) in 2010. This figure will increase to $10 \%$ in 2020. According to NORA statistics, the biofuel penetration rate reached $2.2 \%$ in 2010 . The fuel blend reached $3.26 \%$ for the first 7 months in 2012 [2].

Both European and Irish biofuel policies fail to incorporate other alternative fuels at present. It is important that these policies are updated to allow the contribution of other alternative fuels, such as synthetic diesel, to the European and national renewable energy targets. Synthetic diesels are diesel-like fuels produced from sources other than biological materials or crude petroleum oil.

\subsection{EN 590:2009 Fuel Standards}

Fuels are required to meet certain fuel specifications to ensure adequate performance in spark and compression combustion engines. When these specifications are met, 
biodiesel can be used in the most modern engines without any modification while maintaining the engines durability and reliability [3]. The European fuel standard, EN 590: 2009, specifies property limits which marketable fuels must conform to. The standard also outlines test procedures which are to be followed to accurately determine these properties for fuels $[4,5]$.

When tested using the standard test methods indicated in Table 1, below, marketable automotive diesel fuel properties must be within the limits for flash point (FP) specified in these tables. The test methods listed in Table $\mathbf{1}$ have been assessed for application to automotive diesel containing up to $7 \%$ (V/V) fatty acid methyl ester (FAME) [5]. Table 2 shows the temperature limits for different grades of diesel fuel relative to the cold filter plugging point (CFPP).

Table 1. Generally Applicable Requirements and Test Methods EN 590: 2009 [5]

\begin{tabular}{|c|c|c|c|c|}
\hline \multirow{2}{*}{ Property } & \multirow{2}{*}{ Unit } & \multicolumn{2}{|c|}{ Limits } & \multirow{2}{*}{ Test Method } \\
\cline { 3 - 4 } & & Minimum & Maximum & \\
\hline \hline FP & ${ }^{\circ} \mathrm{C}$ & 55 & - & EN 3675, EN 12185 \\
\hline
\end{tabular}

\subsection{Fuel Properties}

\subsubsection{Cold Filter Plugging Point}

The CFPP is defined in the European Standard EN 116:2009 as "the highest temperature at which a given volume of fuel fails to pass through a standardised filtration device in a specified time, when cooled under standardised conditions" [6]. The cold-filter plugging point is a key cold flow property for diesel.

\subsubsection{Flash Point}

FP is defined in the European Standard EN 2719:2002 as the "lowest temperature of the test portion, corrected to a barometric pressure of $101,3 \mathrm{kPa}$, at which the application of an ignition source causes the vapour of the test portion to ignite and the flame to propagate across the surface of the liquid under the specified conditions of test" [7]. The FP is a measure of the tendency of a sample to form flammable mixtures with air in controlled laboratory conditions. It is a parameter important for the handling, storage, and safety of fuels as it gives an indication of fire risk in storage under ambient conditions [8].

\subsection{Fuel Blending}

In light of the EU requirements relating to biofuels outlined above, blending of alternative diesel fuels with conventional petroleum diesel has taken on added importance. The majority of research has been carried out on blending several types of biodiesel [9-11], with conventional diesel. Fewer studies have dealt with alternative fuels from other feedstock. These feedstock include straight vegetable oil [12], waste polystyrene [13], biomass [14]. Few studies examine the effect of blending of fuels derived from plastic with diesel.

Blending allows the adjustment of fuel properties in line with EU standards while achieving the targets outlined in the EU Directive on the promotion and use of energy from renewable sources.

The fuel properties of biodiesel, Cyn-diesel and other alternative fuels differ from conventional diesel. Key fuel properties such as viscosity, density and cold flow properties have an important effect on engine performance. Therefore, an understanding of the fuel properties of alternative diesels fuels and their blends is important before using such blends in a diesel engine [3].

\subsubsection{Blending - Properties}

The blending of alternative diesel fuels at differing levels with conventional diesel can have a significant effect on blend fuel properties such as FP and cold flow properties. Extensive research has been carried out on the properties of alternative fuels and blends with petroleum diesel $[3,9,11$ $16]$.

\subsubsection{Blending - Cold Filter Plugging Point}

There is a dearth of literature reporting the CFPP of synthetic diesel produced from materials other than biomass or conventional petroleum diesel. The majority of the research on cold flow properties of fuel blends focuses on biodiesels. This may be the case as, depending on feedstock, biodiesel has relatively poor cold flow properties in comparison to conventional diesel, which may limit its distribution in moderate temperature climates. The poor cold flow properties of biodiesel may cause problems in the start of engine and limits the use of biodiesel in cold climates [3, 10]. The major limitation of a biodiesel derived from raw materials is its tendency to crystallise or gel at a high CFPP, which can plug an engine filter [17].

Researchers have investigated several approaches to improving the low-temperature problems of biodiesel, including blending it with conventional petroleum diesel [10]. Jeong et al. [17] carried out a project aimed at estimating and improving CFPPs by blending biodiesels with different fatty acid contents. In order to determine whether biodiesel could impart its desirable low temperature properties to a blended biodiesel containing other constituents, blended samples were prepared containing soybean (SME), rapeseed (RME), palm (PME), and lard (LME) biodiesels manufactured from several origins at different percent weight ratios, as follows: 20:80, 40:60, 50:50, 60:40, and 80:20. The lard or palm biodiesels, which contained high levels of saturated fatty acids, were blended

Table 2. Climate-Related Requirements and Test Methods - Temperate Climates EN 590: 2009 [5]

\begin{tabular}{|c|c|c|c|c|c|c|c|}
\hline \multirow{2}{*}{ Property } & \multirow{2}{*}{ Unit } & \multicolumn{9}{|c|}{ Limits } & \multirow{2}{*}{ Test Method } \\
\cline { 3 - 9 } & & Grade A & Grade B & Grade C & Grade D & Grade E & Grade F \\
\hline \hline CFPP & ${ }^{\circ} \mathrm{C}$ & +5 & 0 & -5 & -1 & -15 & -20 \\
\hline
\end{tabular}


with soybean or rapeseed biodiesels, which contained low saturated fatty acid levels. It was found in each case that increasing the high-unsaturated to high-saturated blending ratio decreased the CFPP of the mixture linearly [17].

Miskolczi, Bartha et al. [18] reported the effects of different catalysts on the degradation of waste plastics (polyethylene and polystyrene) into liquid hydrocarbons. It was found that, depending on the catalyst used, the CFPP of the liquid hydrocarbon ranged between $+1^{\circ} \mathrm{C}$ and $-8^{\circ} \mathrm{C}$. Prathmesh and Paresh [19] report a high CFPP of $8^{\circ} \mathrm{C}$ for tyre derived oil. Such a high CFPP would mean that this tire derived oil would fail to meet even Grade A of the EN 590 standards for CFPP if used in its pure, unblended form.

\subsubsection{Blending - Flash Point}

As described previously, the use of polystyrene (PS) as a fuel in diesel engines has been investigated as an option for energy recovery from waste plastics. Biodiesel was used as a recycling agent and polystyrene packing peanuts were dissolved in biodiesel in different concentrations as a means to recover energy from waste plastics. PS packing peanuts were dissolved at concentrations of $2 \%, 5 \%, 10 \%, 15 \%$, and $20 \%$ PS by weight in biodiesel at room temperature. The FPs of diesel No.2, $100 \%$ biodiesel and each of the blends was determined according to ASTM test methods. The FPs of the biodiesel and PS peanuts were found to be $139{ }^{\circ} \mathrm{C}$ and 266 ${ }^{\circ} \mathrm{C}$ respectively. The FPs of the blends were found to decrease with increasing concentration of PS [13].

Several studies have been carried out which evaluate the properties of waste plastic oil, tyre pyrolysis oil and diesel fuel [20-23]. Murugan, Ramaswamy et al. [21] examined the FP of tyre pyrolysis oil (TPO) derived from waste automobile tyres through vacuum pyrolysis. It was found that the diesel fuel had a FP of $50^{\circ} \mathrm{C}$ while the TPO had a lower FP of $43^{\circ} \mathrm{C}$ [21]. Mani, Ramaswamy et al. [20] further examined the FPs of the crude TPO, distilled tyre pyrolysis oil (DTPO), and two distilled tyre pyrolysis oil - diesel fuel blends. The results can be seen in Table 3, below. The results highlight that the FP of the blend decreases with increasing DTPO content.

Table 3. Comparison of TPO, DTPO, DTPO 20 and DPTO 90 Blends with Diesel [20]

\begin{tabular}{|c|c|c|c|c|c|}
\hline Property & Diesel & Crude TPO & DTPO & DTPO 20 & DPT0 90 \\
\hline \hline FP, ${ }^{\circ} \mathrm{C}$ & 50 & 43 & 36 & 47 & 37 \\
\hline
\end{tabular}

Mani, Subash et al. [23] analysed the FP of oil derived from waste plastics and compared this with the FP of diesel. It was found that the FP of the waste plastic oil was $42^{\circ} \mathrm{C}$, lower than that of diesel which was found to be $50^{\circ} \mathrm{C}$. Another study confirms the low FP of tyre pyrolysis oil at $43^{\circ} \mathrm{C}$ [24].

Doğan, Çelik et al. [25] and İlkılıç and Aydın [26] both reported higher FPs of diesel than other studies, at $67^{\circ} \mathrm{C}$ and $60^{\circ} \mathrm{C}$ respectively. Both studies found the FP of tire-derived fuels, $60.5^{\circ} \mathrm{C}$ [25] and $50^{\circ} \mathrm{C}$ [26] to lower than the conventional petroleum diesel they tested. A lower FP results in lower volatility of the fuel which can provide better mixing rate in the combustion chamber, and lower the smoke emissions [25].

The literature review highlights the effectiveness of blending various alternative fuels with conventional petroleum diesel fuel in altering the resulting fuel blends' properties. There is a gap in the literature in assessing the properties of blends of synthetic diesel fuel derived from waste plastics with conventional petroleum diesel. It is hoped that this paper will provide a relevant assessment of the CFPP and FP of Cyn-diesel blends with conventional petroleum diesel. It is hoped this work will complement existing research into the properties of alternative fuels and blends of these fuels with conventional petroleum diesel.

\section{MATERIALS AND METHODS}

The synthetic pyrolysis fuel for the project was obtained from Cynar PLC, a plastic waste-to-energy company based in Ireland, the first plant with this technology in Europe. This Cyn-diesel was produced by the pyrolysis of waste plastics as described in the section on pyrolysis above. Standard whiteroad diesel was also obtained for preparing blends with the Cyn-diesel. Road diesel in Ireland is specified by the standard EN590. All crude oil imported into Ireland is refined to this standard by ConocoPhillips Ireland Ltd refinery based in White gate in Co Cork (southern Ireland) and the sample was purchased at a standard fuel supplier in Ireland. Some key parameters of the fuel were cetane index 55.6 , density $837.2 \mathrm{~kg} / \mathrm{m}^{3}$, kinematic viscosity $2.97 \mathrm{~mm}^{2} / \mathrm{s}$, sulphur $<10 \mathrm{ppm}$, flash point $67.3{ }^{0} \mathrm{C}$, cloud point $-1{ }^{0} \mathrm{C}$, CFPP $-13{ }^{\circ} \mathrm{C}$. Similarly for cyn-diesel, key parameters of the fuel were cetane index 70 , density $794.4 \mathrm{~kg} / \mathrm{m}^{3}$, kinematic viscosity $1.85 \mathrm{~mm}^{2} / \mathrm{s}$, sulphur <10ppm (4.2), flash point $45.3{ }^{\circ} \mathrm{C}$, cloud point $-4{ }^{0} \mathrm{C}$, CFPP $+2{ }^{0} \mathrm{C}$.

Cyn-diesel was blended at room temperature with conventional petroleum diesel in ratios of $10 \%, 20 \%, 30 \%$, $40 \%$ and 50\% Cyn-dieselby volume. The samples were agitated by hand to ensure homogeneity. Samples of pure diesel and Cyn-diesel were also used for analysis.

The EN 590 standard specifies test methods and procedures which should be followed in the testing of fuel properties in relation to compliance with EN 590. As such, these methods were followed as closely as possible in this study in order to ensure conformity to standard methods.

The standard governing the measurement of CFPP is EN 116:2009 - 'Diesel and domestic heating fuels determination of cold filter plugging point'. This method requires a range of equipment including a pipette, filter unit, cooling bath vacuum regulator [6]. The standard governing the measurement of FP is EN 2719:2002 - 'Determination of FP - Pensky Martens closed cup method'. This method requires the use of a Pensky-Martens closed cup module [7].

\subsection{Determination of Cold Filter Plugging Point}

The CFPP was determined using CFPP V test equipment and a vacuum device by PetroTest. The test procedure was carried out in accordance with the EN 116 standard procedure for CFPP testing, as specified in the EN 590 standard [6]. The CFPP V equipment was calibrated using a sample standard. 
CFPP was initially measured for each of the 7 different blends. 4 replications were carried out for each blend. After analysing the results in relation to the EN 590 specifications, 4 further blends were tested; $60 \%, 70 \%, 80 \%$ and $90 \%$ Cyndiesel.

\subsection{Determination of Flash Point}

The FP was determined using a MultiflashPenskyMartens closed cup module (34100-2) by Stanhope-Seta. The test procedure was carried out in accordance with the EN 2719 standard procedure for FP testing, as specified in the EN 590 standard [7]. The Multiflash unit is programmed to automatically carry out the procedure according to the EN 2719 standard. The unit was calibrated using a sample standard prior to the start of the experimental procedure.

FP was measured for each of the 7 different blends.

\subsection{Statistical Analysis}

\subsubsection{T-Test for Significance}

The t-test for significance, carried out using SAS, was used to determine whether the observed differences in responses (i.e. values of CFPP, and FP) are due to the treatments (i.e. differing blend ratios of Cyn-diesel vs regular fossil diesel) or simply random variation. The purpose of significance testing is to ensure that the experimenter does not try to interpret random variation. The output of interest from the t-test is the $\mathrm{P}$ value. If the $\mathrm{P}$ value is small it may be used to reject the null hypothesis (i.e. that the observed difference between means is due to chance) as not credible. Ultimately, if the $\mathrm{P}$ value is small $(<0.05)$, it can be said with a reasonable amount of confidence that the observed effects were due to treatment effects [27].

\subsubsection{Regression Analysis}

Regression analysis can be used to determine the contributory effect of one variable upon another - in the case of this project, the effect of increasing Cyn-diesel concentration in the fuel blend on selected fuel properties (CFPP and FP). The regression analysis is utilised to estimate the quantitative effect of the causal variables upon the variable that they influence [27]. In regression, the $\mathrm{R}^{2}$ value is a statistical measure of how well the regression line approximates the real data points. An $R^{2}$ of 1.0 indicates that the regression line perfectly fits the data. The $\mathrm{R}^{2}$ value is calculated by expressing the regression (model) sum of squares statistic as a percentage of the total sum of squares.

The regression analysis was carried out using SAS statistical analysis software.

\section{RESULTS}

\subsection{Cold Filter Plugging Point}

Table 4, below, outlines the results of the experimental procedure carried out with the CFPP V test equipment.

The results of the first round of CFPP testing (up to $50 \%$ Cyn-diesel and 100\% Cyn-diesel) of the fuel blends obtained (Table 4) can be compared to the EN 590 CFPP requirements outlined in Table $\mathbf{5}$ below. The EN 590 standards for CFPP specify different seasonal grades of fuel with specific CFPPs. Each grade represents the time period across a year in which the fuel would be suitable for use based on its CFPP. Grade A would be a summer fuel as it has a high CFPP, which is appropriate as the fuel would not 'plug' as summer temperatures are quite high. However, Grade F would be a winter fuel as its CFPP is very low, as such the fuel would not 'plug' even in the cold temperatures of winter. Comparing the mean CFPP of each of the blends with this requirement, it was clear that the each of the blends fit into different seasonal grades. It was therefore decided to examine the intermediate blends between $50 \%$ and $100 \%$ Cyn-diesel to determine which grades those blends would fit into. The $80 \%, 90 \%$ and $100 \%$ Cyn-diesel blends are Grade A fuels. The $40 \%, 50 \%, 60 \%$ and $70 \%$ Cyn-diesel blends are Grade B fuels. The $20 \%$ and $30 \%$ Cyn-diesel blends are Grade C fuels. The 10\% Cyn-diesel and diesel blends are Grade E fuels. As such, the different blends are in compliance with EN 590 seasonal grade requirements in terms of CFPP.

\section{Table 4. CFPP Results}

\begin{tabular}{|c|c|c|c|c|c|c|}
\hline \multicolumn{6}{|c|}{ CFPP $\left({ }^{\circ} \mathrm{C}\right)$} & \multirow{2}{*}{ STDEV } \\
\hline & $\operatorname{Rep} 1$ & Rep 2 & $\operatorname{Rep} 3$ & $\operatorname{Rep} 4$ & Mean CFPP $\left({ }^{\circ} \mathbf{C}\right)$ & \\
\hline Diesel & -13 & -13 & -13 & -12 & -13 & 1 \\
\hline $10 \%$ Cyn-diesel & -10 & -11 & -11 & -11 & -11 & 1 \\
\hline $20 \%$ Cyn-diesel & -9 & -8 & -8 & -8 & -8 & 1 \\
\hline $30 \%$ Cyn-diesel & -5 & -5 & -5 & -5 & -5 & 0 \\
\hline $40 \%$ Cyn-diesel & -3 & -3 & -3 & -3 & -3 & 0 \\
\hline 50\% Cyn-diesel & -2 & -2 & -1 & -2 & -2 & 1 \\
\hline $60 \%$ Cyn-diesel & -1 & -1 & -1 & -1 & -1 & 1 \\
\hline 70\% Cyn-diesel & 0 & -1 & 0 & 0 & 0 & 1 \\
\hline $80 \%$ Cyn-diesel & 1 & 1 & 2 & 1 & 1 & 1 \\
\hline $90 \%$ Cyn-diesel & 2 & 2 & 2 & 2 & 2 & 0 \\
\hline $100 \%$ Cyn-diesel & 3 & 3 & 4 & 3 & 3 & 1 \\
\hline
\end{tabular}


Table 5. FP Results

\begin{tabular}{|c|c|c|c|c|c|c|}
\hline & $\operatorname{Rep} 1$ & $\operatorname{Rep} 2$ & $\operatorname{Rep} 3$ & $\operatorname{Rep} 4$ & Mean FP $\left({ }^{\circ} \mathrm{C}\right)$ & STDEV \\
\hline $10 \%$ Cyn-diesel & 63.5 & 65.5 & 64.5 & 65.0 & 64.6 & 0.9 \\
\hline $20 \%$ Cyn-diesel & 61.5 & 62.5 & 62.0 & 62.5 & 62.1 & 0.5 \\
\hline $40 \%$ Cyn-diesel & 55.5 & 56.5 & 55.0 & 56.0 & 55.8 & 0.6 \\
\hline $50 \%$ Cyn-diesel & 53.0 & 53.0 & 52.0 & 52.0 & 52.5 & 0.6 \\
\hline $100 \%$ Cyn-diesel & 44.5 & 45.5 & 46.0 & 45.0 & 45.3 & 0.6 \\
\hline
\end{tabular}

\subsection{Flash Point}

Table 5, below, gives the results of the experimental procedure carried out with the Pensky-Martens closed cup module.

The results of the FP testing of the fuel blends obtained (Table 5) can be compared to the EN 590 FP requirements outlined in Table 7 below. The EN 590 standard for FP specifies that the fuel must have a minimum $\mathrm{FP}$ of $55^{\circ} \mathrm{C}$. Comparing the mean FPs of each of the blends with this requirement, it is clear that blends up to, and including, $40 \%$ Cyn-diesel content have FPs above the required value. Blends containing 50\% and 100\% Cyn-diesel lie below the required FP value. Therefore, blends above 50\% were not tested as they were outside the required range. As such, blends up to, and including $40 \%$ Cyn-diesel content are in compliance with EN 590 requirements in terms of FP. The blends containing 50\% and 100\% Cyn-diesel are not in compliance with EN 590 standards.

\subsection{Statistical Analysis Results}

\subsubsection{T-test for Significance}

\section{$\underline{3.3 .1 .1 . ~ C o l d ~ F i l t e r ~ P l u g g i n g ~ P o i n t ~}$}

Table 6, below, gives the output from the t-test for significance for the CFPP results from the CFPP $\mathrm{V}$ test equipment. Again, the "Pr $>F$ " value in is less than 0.0001 . Such a value is extremely low and again signifies that blending of Cyn-diesel and conventional petroleum diesel has a highly significant effect on the observed differences in CFPP.

Table 6. SAS Output from t-Test for Significance for CFPP

\begin{tabular}{|c|c|c|c|c|c|}
\hline \multicolumn{7}{|c|}{ The GLM Procedure } \\
\hline Source & DF & $\begin{array}{c}\text { Sum of } \\
\text { Squares }\end{array}$ & $\begin{array}{c}\text { Mean } \\
\text { Square }\end{array}$ & $\begin{array}{c}\text { F } \\
\text { Value }\end{array}$ & Pr> F \\
\hline \hline Model & 6 & 667.9 & 111.3 & 467.5 & $<.0001$ \\
\hline Error & 21 & 5.0 & 0.2 & & \\
\hline Corrected Total & 27 & 672.9 & & & \\
\hline
\end{tabular}

\subsubsection{Flash Point}

The output from the t-test for significance for the FP results from the Pensky-Martens closed cup module is given in Table 7, below. The "Pr>F" value in this case is less than 0.0001 , yet again validating that blending of Cyn-diesel with conventional petroleum diesel in differing ratios has a highly significant effect on the observed differences in FP.

Table 7. SAS Output from t-Test for Significance for FP

\begin{tabular}{|c|c|c|c|c|c|}
\hline \multicolumn{7}{|c|}{ The GLM Procedure } \\
\hline Dependant Variable: FP \\
\hline Source & DF & $\begin{array}{c}\text { Sum of } \\
\text { Squares }\end{array}$ & $\begin{array}{c}\text { Mean } \\
\text { Square }\end{array}$ & F Value & Pr> F \\
\hline \hline Model & 6 & 1387.2 & 231.2 & 288.8 & $<.0001$ \\
\hline Error & 21 & 16.8 & 0.8 & & \\
\hline Corrected Total & 27 & 1404.0 & & & \\
\hline
\end{tabular}

The t-test for significance analysis highlights that for all properties examined; blending of Cyn-diesel with conventional petroleum diesel in differing ratios has a highly significant effect on the observed responses. As such, blending of Cyn-diesel with conventional petroleum diesel imparts a significant change on the properties of the fuel blend. This implies that blending is an appropriate method of achieving a fuel blend with desired properties.

\subsubsection{Regression Analysis Results}

\section{$\underline{\text { 3.3.2.1. Cold Filter Plugging Point }}$}

A linear regression model was applied to the CFPP results from the experimental procedure. Table $\mathbf{8}$ below, gives the output from the regression analysis in SAS. The regression analysis gives an $R^{2}$ value of 0.94 . This $R^{2}$ value indicates that a linear relationship approximates the data well. An equation can be obtained from the regression analysis which can be used to predict the variation of $y$ (CFPP) according to the change in $\mathrm{x}$ (Cyn-diesel content). The following equation is determined from the table below: $\mathrm{y}=0.21 \mathrm{x}-12.34$. 
The P_synd parameter in the table below, gives the slope of the line. This parameter implies that for each percentage increase in Cyn-diesel in the fuel blend, the cold filter plugging point increases by $0.21^{\circ} \mathrm{C}$. Consequently, increasing the Cyn-diesel content of the fuel blend results in an increase in CFPP.

Table 8. Regression Analysis Output from SAS for CFPP

\begin{tabular}{|l|c|c|c|c|c|}
\hline \multicolumn{7}{|c|}{ The GLM Procedure } \\
\hline \multicolumn{7}{|c|}{ Source } & DF & $\begin{array}{c}\text { Sum of } \\
\text { Squares }\end{array}$ & $\begin{array}{c}\text { Mean } \\
\text { Square }\end{array}$ & F Value & Pr $>$ F \\
\hline \hline Model & 1 & 488.89 & 579.07 & 670.27 & $<.0001$ \\
\hline Error & 26 & 18.97 & 0.73 & & \\
\hline Corrected Total & 27 & 507.86 & & & \\
\hline $\mathbf{R}^{2}$ & \multicolumn{7}{|c|}{0.94} \\
\hline Coefficient of Variation & \multicolumn{7}{|c|}{-14.07} \\
\hline Root MSE & \multicolumn{7}{|c|}{0.85} \\
\hline Parameter & \multicolumn{7}{|c|}{ Estimate } & $\begin{array}{c}\text { Standard } \\
\text { Error }\end{array}$ & t Value & Pr $>\mathbf{t}$ \\
\hline \hline Intercept & \multicolumn{7}{|c|}{$-12.34{ }^{\circ} \mathrm{C}$} & 0.29 & -42.41 & $<.0001$ \\
\hline P_synd & $0.21{ }^{\circ} \mathrm{C} / \%$ & 0.01 & 25.89 & $<.0001$ \\
\hline
\end{tabular}

Fig. (1) shows the regression line applied to CFPP $v s$ Cyn-diesel content. On examining the graph, it is clear that the regression line is a good fit for the relationship between the CFPP of the fuel blend and the Cyn-diesel content of the blend.

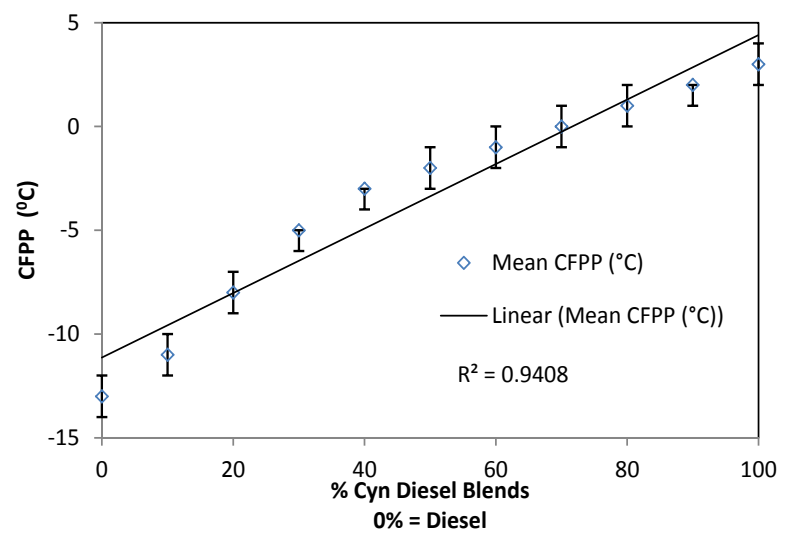

Fig. (1). CFPP $\left({ }^{\circ} \mathrm{C}\right)$ vs Cyn-diesel content (\%) showing standard deviation.

\subsubsection{Flash Point}

Table 9 below, gives the output from the regression analysis applied to the FP results obtained from the experimental procedure. In this case, the regression analysis gives an $R^{2}$ value of 0.96 . This high $R^{2}$ value indicates that a linear relationship approximates the correlation between the FP of the fuel blend and the percentage Cyn-diesel content very well. An equation can be obtained from the regression analysis which can be used to predict the variation of $y$ (FP) according to the change in $x$ (Cyn-diesel content). The following equation is determined from the table below: $\mathrm{y}=-$ $0.2 \mathrm{x}+66.2$.

The $\mathrm{P} \_$synd parameter in the table below, gives the slope of the line. This parameter implies that for each percentage increase in Cyn-diesel in the fuel blend, the FP decreases by $-0.2^{\circ} \mathrm{C}$. Consequently, increasing the Cyn-diesel content of the fuel blend results in a decrease in FP.

Table 9. Regression Analysis Output from SAS for FP

\begin{tabular}{|c|c|c|c|c|c|c|}
\hline \multicolumn{7}{|c|}{ The GLM Procedure } \\
\hline \multicolumn{7}{|c|}{ Dependant Variable: FP } \\
\hline Source & DF & $\begin{array}{l}\text { Sur } \\
\text { Squ }\end{array}$ & & $\begin{array}{l}\text { Mean } \\
\text { Square }\end{array}$ & F Value & $\operatorname{Pr}>\mathbf{F}$ \\
\hline Model & 1 & 133 & & 1338.12 & 527.86 & $<.0001$ \\
\hline Error & 26 & & & 2.53 & & \\
\hline Corrected Total & 27 & & & & & \\
\hline $\mathbf{R}^{2}$ & \multicolumn{6}{|c|}{0.96} \\
\hline \multicolumn{3}{|c|}{ Coefficient of Variation } & \multicolumn{3}{|c|}{2.74} & \\
\hline Root MSE & \multicolumn{6}{|c|}{1.59} \\
\hline Parameter & Esti & late & & $\begin{array}{l}\text { tandard } \\
\text { Error }\end{array}$ & t Value & $\operatorname{Pr}>t$ \\
\hline Intercept & 66. & & & 0.5 & 143.3 & $<.0001$ \\
\hline P_synd & -0. & & & 0.01 & -23.0 & $<.0001$ \\
\hline
\end{tabular}

Fig. (2) shows that the regression line is a good fit for the relationship between the FP of the fuel blend and the Cyndiesel content of the blend.

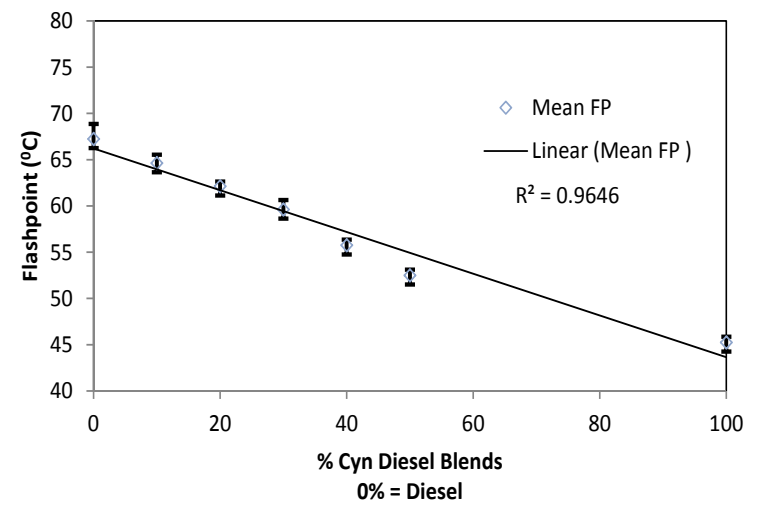

Fig. (2). FP $\left({ }^{\circ} \mathrm{C}\right)$ vs Cyn-diesel content (\%) showing standard deviation.

\section{DISCUSSION}

The statistical analysis of the experimental results confirms that the blending of Cyn-diesel with conventional petroleum diesel has a highly significant $(\mathrm{P}<0.0001)$ effect on each of the fuel blends' properties examined. As such, it is clear that the Cyn-diesel used in this study can be blended with conventional petroleum diesel to ensure conformance with EN 590 specifications for the properties investigated.

The main aim of this paper was to analyse certain properties of blends of Cyn-diesel vs regular road diesel fuel 
in relation to compliance with EN 590 standards. The results from the experimental procedure allow the evaluation of the fuel blend properties in relation to compliance with the standards required in EN 590. As can be seen in the results section, the comparison of the properties of the fuel blends to the EN 590 standards results in a number of trends. Firstly, all blends are in compliance with EN 590 specifications in relation to CFPP, as each blend complies with different seasonal blend requirements. However, only blends of up to and including 40\% Cyn-diesel are in compliance with EN 590 specifications for FP. This analysis shows that a blend of $40 \%$ Cyn-diesel is in compliance with all of the EN 590 specifications examined, and as such could be placed on the European fuel market.

The t-test for significance highlights that blending has a highly significant $(\mathrm{P}<0.0001)$ effect on the CFPP of the fuel blend. The regression analysis shows that for each percentage increase in Cyn-diesel in the fuel blend, the FP increases by $0.21^{\circ} \mathrm{C}$. Consequently, by increasing the Cyndiesel content of the fuel blend results in an increase in CFPP.

Similarly, the statistical analysis indicates that blending has a highly significant $(\mathrm{P}<0.0001)$ effect on the FP of the fuel blend. The regression analysis shows that for each percentage increase in Cyn-diesel in the fuel blend, the FP decreases by $0.2^{\circ} \mathrm{C}$. As such, by increasing the Cyn-diesel content of the fuel blend results in a decrease in FP.

As discussed above, the statistical analysis of the results show that blending has a significant $(\mathrm{P}<0.0001)$ of the properties of the fuel blend. Subsequently, the null hypothesis (blending has no effect on fuel blend properties) can be rejected.

As discussed previously, the review of the literature pertaining to the properties of fuel blends highlights the effectiveness of blending various alternative fuels with conventional petroleum diesel fuel in altering the resulting fuel blends' properties. However, there is a gap in the literature in assessing the properties of blends of synthetic diesel fuel derived from waste plastics with conventional petroleum diesel. It is hoped that this project will provide a relevant assessment of the CFPP and FP of Cyn-diesel blends with conventional petroleum diesel. It is hoped this work will complement existing research into the properties of alternative fuels and blends of these fuels with conventional petroleum diesel.

\section{CONCLUSION}

Several key findings have emerged as a result of this project.

Firstly, it can be confirmed that blending of Cyn-diesel with conventional petroleum diesel has a highly significant effect on the properties of the resulting fuel blend. The results show that by increasing the Cyn-diesel content of the blend, the FP of the blend decreases. While increasing the Cyn-diesel content of the blend results in an increase in CFPP.

Secondly, the evaluation of compliance of the fuel blends in relation to EN 590 specifications has shown differing results. The CFPP, of all of the fuel blends are in compliance with EN 590 specifications. However, only blends of up to, and including, 40\% Cyn-diesel are in compliance with EN 590 specifications for FP. This analysis shows that a blend of $40 \%$ Cyn-diesel is in compliance with all of the EN 590 specifications examined, and as such could be placed on the European fuel market (provided that the blend meets the requirements for the other properties in the EN 590 specification). This finding highlights the potential for Cyndiesel blends to be incorporated into the European and national renewable energy targets.

The next step would be to carry out a full characterisation of the fuel blends in relation to the other properties in the EN 590 specification. This would enable the evaluation of blends of Cyn-diesel with conventional diesel fuel in relation to compliance with the full range of properties included in the EN 590 fuel specification.

\section{CONFLICT OF INTEREST}

The authors confirm that this article content has no conflict of interest.

\section{ACKNOWLEDGEMENTS}

This research was funded under Science Foundation Ireland's Charles Parsons Award 06/CP/E001 www.sfi.ie

\section{REFERENCES}

[1] EC EC-. Directive 2009/28/EC of the European Parliament and of the Council of 23 April 2009 on the promotion of the use of energy from renewable sources and amending and subsequently repealing Directives 2001/77/EC and 2003/30/EC, 2009.

[2] NORA NORA-. Statistics, 2012.

[3] Alptekin, E.; Canakci, M. Determination of the density and the viscosities of biodiesel-diesel fuel blends. Renewable Energy, 2008, 33(12), 2623-2630.

[4] CEN ECfS-. EN 14214:2008 - Automotive fuels - Fatty acid methyl esters (FAME) for diesel engines - Requirements and test methods.Organisation BS, 2008.

[5] CEN, European Committee for Standardization. EN 590:2009 Automotive fuels - Diesel - Requirements and test methods. In: Organisation BS, ed., 2009.

[6] CEN ECfS-. EN 590:2009 - Automotive fuels - Diesel Requirements and test methods. Organisation BS, 2009.

[7] CEN, European Committee for Standardization. EN 2719:2002 Determination of flash point - Pensky Martens closed cup method. Organisation BS,2002.

[8] Rashid, U.; Anwar, F.; Knothe, G. Evaluation of biodiesel obtained from cottonseed oil. Fuel Process. Technol., 2009, 90(9), 11571163.

[9] Tat, M.; Van Gerpen, J. The kinematic viscosity of biodiesel and its blends with diesel fuel. J. Am. Oil Chem. Soc., 1999, 76(12), 15111513.

[10] Sharma, BK.; Suarez, Paz.; Perez, JM.; Erhan SZ. Oxidation and low temperature properties of biofuels obtained from pyrolysis and alcoholysis of soybean oil and their blends with petroleum diesel. Fuel Process. Technol., 2009, 90(10), 1265-1271.

[11] Pramanik, K. Properties and use of jatropha curcas oil and diesel fuel blends in compression ignition engine. Renewable Energy, 2003, 28(2), 239-248.

[12] Abollé, A.; Kouakou, L.; Planche, H. The viscosity of diesel oil and mixtures with straight vegetable oils: Palm, cabbage palm, cotton, groundnut, copra and sunflower. Biomass Bioenergy, 2009, 33(9): 1116-1121.

[13] Kuzhiyil, N.; Kong, S-C. Energy Recovery from Waste Plastics by Using Blends of Biodiesel and Polystyrene in Diesel Engines. Energy Fuels, 2009, 23(6), 3246-3253.

[14] Wu, T.; Huang, Z.; Zhang, WG.; Fang, J-h.; Yin, Q. Physical and Chemical Properties of GTL Diesel Fuel Blends and Their Effects on Performance and Emissions of a Multicylinder DI Compression Ignition Engine. Energy Fuels, 2007, 21(4), 1908-1914.

[15] Abollé, A.; Loukou, K.; Henri, P. The density and cloud point of diesel oil mixtures with the straight vegetable oils (SVO): Palm, 
cabbage palm, cotton, groundnut, copra and sunflower. Biomass and Bioenergy, 2009, 33(12), 1653-1659.

[16] Luján, JM.; Tormos, B.; Salvador, FJ.; Gargar, K. Comparative analysis of a DI diesel engine fuelled with biodiesel blends during the European MVEG-A cycle: Preliminary study (I). Biomass Bioenergy, 2009, 33(6-7), 941-947.

[17] Jeong, G.T.; Park, J.H.; Park, S.H.; Park, D.H. Estimating and Improving Cold Filter Plugging Points by Blending Biodiesels with Different Fatty Acid Contents. Biotechnol. Bioprocess. Eng., 2008, 13(4), 505-510.

[18] Miskolczi, N.; Bartha, L.; Deák, G. Thermal degradation of polyethylene and polystyrene from the packaging industry over different catalysts into fuel-like feed stocks. Polym. Degrad. Stab., 2006, 91(3), 517-526.

[19] Bhatt Prathmesh, M.; Patel Paresh, D. Suitability of tyre pyrolysis oil (TPO) as an alternative fuel for internal combustion engine. IJAERS, 2012, 1(4): 61-65.

[20] Mani, M.; Ramaswamy, MC.; Nagarajan, G. A comparative study on the performance, emission and combustion studies of a DI diesel engine using distilled tyre pyrolysis oil-diesel blends. Fuel, 2008, 87(10-11), 2111-2121.
[21] Murugan, S.; Ramaswamy, MC.; Nagarajan G. The use of tyre pyrolysis oil in diesel engines. Waste Manag., 2008, 28(12), 27432749.

[22] Mani, M.; Subash, C.; Nagarajan G. Performance, emission and combustion characteristics of a DI diesel engine using waste plastic oil. Appl. Therm. Eng., 2009, 29(13), 2738-2744.

[23] Mani, M.; Nagarajan, G.; Sampath S. Characterisation and effect of using waste plastic oil and diesel fuel blends in compression ignition engine. Energy, 2011, 36(1), 212-219.

[24] Hariharan, S.; Murugan, S.; Nagarajan, G. Effect of diethyl ether on Tyre pyrolysis oil fueled diesel engine. Fuel, 2013, 104, 109115.

[25] Doğan, O.; Çelik, MB.; Özdalyan, B. The effect of tire derived fuel/diesel fuel blends utilization on diesel engine performance and emissions. Fuel, 2012, 95, 340-346.

[26] İlkılıç, C.; Aydın, H. Fuel production from waste vehicle tires by catalytic pyrolysis and its application in a diesel engine. Fuel Process. Technol., 2011, 92(5), 1129-1135.

[27] Connolly, J. Postgraduate Research Methods for the Life Sciences. Department of Statisitcs: University College Dublin, 2007. 